\title{
SEKOLAH DAN PENDIDIKAN KARAKTER ISLAMI (Sebuah Analisis Konseptual)
}

\section{Ramin}

\section{Balai Diklat Keagamaan Bandung, Indonesia}

*E-mail: raminmuttaqien@gmail.com

\begin{abstract}
The problem of the nation's character until now and even in the future remains an interesting discussion for practitioners and observers. Thinking about the right formula to educate the character of the young generation as the nation's successors is baing more focused in this country now. The busyness of parents, social environment, community, and social media have a role in shaping adolescent behavior. Adolescents are frequently affected to take actions that reflect bad character. This article is the result of deep thinking with the literature review method on the importance of schools taking a role in educating adolescent characters from references that specifically discuss the theories of character education models. School is a formal institution that possibly changes the role of the family in transferring good character values to students through the form of intra-curricular, cocurricular, extra-curricular, and habituation activities. The end of this article recommends that stakeholders should conceptually know well about the design, model, and character education approach that will be applied.
\end{abstract}

Keywords: Character Education, School, Youth

Abstrak. Masalah karakter bangsa hingga saat ini dan bahkan ke depan masih tetap menjadi diskusi yang menarik bagi praktisi dan pemerhati. Memikirkan formula yang tepat untuk mendidik karakter generasi muda sebagai penerus bangsa adalah fokus yang lebih mengemuka di tanah air ini. Kesibukan orang tua, lingkungan sosial, komunitas, dan termasuk media sosial memiliki andil dalam membentuk perilaku remaja. Tak jarang para remaja terpengaruh, hingga melakukan tindakan-tindakan yang mencerminkan karakter yang buruk. Artikel ini merupakan hasil pemikiran mendalam dengan metode literatur review mengenai pentingnya sekolah mengambil peran dalam mendidik karakter remaja dari referensi yang khusus membabas tentang teori-teori model pendidikan karakter. Sekolah adalah organisasi formal yang sangat memungkinkan mengganti peran keluarga dalam mentransfer nilai-nilai karakter yang baik kepada siswa melalui bentuk kegiatan intra kurikuler, ko-kurikuler, ekstra kurikuler, maupun pembiasaan. Akbir dari artikel ini merekomendasikan babwa stakehorders harus matang secara konseptual mengenai desain, model, dan pendekatan pendidikan karakter yang akan diaplikasikan.

Kata Kunci: Pendidikan Karakter, Sekolah, Remaja 


\section{PENDAHULUAN}

Diskusi karakter di era sekarang merupakan burning issues yang tak hentihenti diangkat oleh para praktisi dan pemerhati, baik dalam skala global dan termasuk di Indonesia. Objek diskusi pun mengarah pada fokus bagaimana mendidik, membina, dan atau menumbuhkan perilaku manusia ke arah yang baik dan lebih baik, tak terkecuali bagi mereka yang berusia remaja.

Remaja merupakan salah satu subjek dengan perilaku yang berada pada masamasa dengan keinginan "kebebasan". Tentu "kebebasan" yang dimaksud adalah kebebasan dalam perspektif mereka.

Masa remaja adalah masa yang unik, yaitu masa yang banyak diliputi oleh kepekaan, karena banyak faktor yang bisa menghantarkan mereka kepada kemungkinan-kemungkinan, baik yang bersifat positif maupun negatif. Dalam perkembangan dan pertumbuhan rohani dan mentalitas, usia remaja masih berada dalam kondisi keguncangan, oleh karena itu sering disebut masa pancaroba dan masa goncang. Hal tersebut sebagaimana yang dikemukakan Zakiyah Darajat bahwa masa remaja adalah masa yang penuh keguncangan jiwa, masa yang berada dalam peralihan atau di atas jembatan goyang, yang menghubungkan masa kanak-kanak yang penuh ketergantungan dengan masa dewasa yang matang dan berdiri sendiri" (Darajat, 1989, 101)

Seorang anak menginjak remaja pada umumnya mempunyai keinginankeinginan untuk selalu mengikuti perkembangan zaman. Sering kita dengar kata "tidak gaul" di kalangan remaja dikarenakan tidak mengikuti trend atau mode anak muda sekarang. Selain itu, tanpa disadari ekses media pun -baik elektronik maupun cetak dan terutama digital- turut mempengaruhi perubahan tingkah laku remaja. Sehingga demikian, tak jarang mereka terjebak pada perilaku negatif bahkan kriminal.

Jika para remaja tidak memiliki karakter yang kuat, dikahwatirkan akan membenuk gaya hidup yang tidak baik dan tidak sesuai dengan gaya hidup nusantara. Masalah-masalah yang lain juga bisa jadi muncul, antara lain ketidakpercayaan diri menjadi pemudapemudi Indonesia, kehilangan fokus belajar, fanatisme terhadap artis idola yang berlebihan, sampai kerugiankerugian ekonomi. Mereka hanya menjadi followers terhadap sesuatu yang bukan "mereka", sedangkan karakter mereka yang asli sebagai anak dari Ibu Pertiwi ini tidak terinternalisasi dengan baik sehingga tidak mampu untuk tegak dan bangga akan dirinya sendiri, sebagai pribadi maupun sebagai pemuda-pemudi Indonesia.

Permasalahan utama sebagaimana uraian sebelumnya adalah adalah buruknya akhlak. Akhlak adalah perangai, kelakuan, tabiat, watak dasar, atau kebiasaan. Akhlak atau khuluq berarti pula budi pekerti, adat kebiasaan, perangai atau semata yang sudah menjadi tabiat. Ia juga sebagai keadaan jiwa seseorang yang mendorongnya untuk melakukan perbuatan-perbuatan tanpa melalui pertimbangan pemikiran terlebih dahulu (Nata, 1996: 1-2; Musthofa, 1997: 12). Jelas sekali bahwa akhlak yang baik harus dilatih dan diberi contoh (Maesaroh et al. 2018.). Latihan tersebut melahirkan pembiasaan yang kemudian melahirkan spontan perilaku yang baik. 
Kebijakan nasional menegaskan bahwa pembangunan karakter bangsa merupakan kebutuhan insani sebagai proses berbangsa dan bernegara. Pentingnya pendidikan akhlak di sekolah diamanatkan Undang-Undang Nomor 20 Tahun 2003 tentang Sistem Pendidikan Nasional Pasal 3 bahwa,

"Pendidikan nasional berfungsi mengembangkan kemampuan dan membentuk watak serta peradaban bangsa yang bermartabat dalam rangka mencerdaskan bangsa, bertujuan untuk berkembangnya potensi peserta didik agar menjadi manusia yang beriman dan bertakwa kepada Tuhan Yang Maha Esa, berakhlak mulia, sehat, berilmu, cakap, kreatif, mandiri dan menjadi warga negara yang demokratis serta bertanggung jawab."

Menjadikan para remaja memiliki karakter yang baik salah satunya adalah peran penting sekolah. Terlebih di Indonesia peran penting tersebut diwujudkan dengan adanya sejumlah mata pelajaran yang mengajarkan karakter kepada siswa, tak terkecuali mata pelajaran pendidikan agama. Dengan demikian, materi yang diberikan kepada siswa mencakup aspek pendidikan keimanan, pendidikan akhlak, pendidikan aqliyah, pendidikan sosial, dan pendidikan jasmaniah (Zainuddin, 1991: 96). Menurut Ahmaf Tafsir, tolak ukur keberhasilan sejumlah mata pelajaran tersebut terletak pada baik buruknya akhlak. Hal itu mengandung maksud bahwa perilaku seseorang akan mencerminkan akhlaknya (Tafsir, 2010).

Di Indonesia upaya tersebut disempurnakan oleh Peraturan Pemerintah Nomor 55 Tahun 2007 Pasal
1 bahwa tujuan pendidikan agama adalah menjadikan siswa taat dalam menjalankan agama.

Artikel ini merupakan hasil pemikiran mendalam dengan metode literatur riview mengenai pentingnya sekolah mengambil peran dalam mendidik karakter remaja dari referensi yang khusus membahas tentang teoriteori model pendidikan karakter. Dimulai dengan mengungkapkan fenomena peprilaku negatif remaja yang kemudia dikaitkan dengan peran dan fungsi sekolah sebagai lembaga pendidikan formal yang sangat memungkinkan untuk melakukan suatu terobosan akademik dalam menggulirkan program-program pendidikan karakter.

\section{METODE PENELITIAN}

Metode yang digunakan dalam penelitian ini adalah deskriptif analisis sesuai dengan karakteristik penelitian ini yang berupaya untuk mengembangkan bahan literasi sebagai bahan pembelajaran PAI. Hal ini sesuai dengan pengertian dari metode deskriptif analitis menurut Sugiono yaitu suatu metode yang berfungsi untuk mendeskripsikan atau memberi gambaran terhadap objek yang diteliti melalui data atau sampel yang telah terkumpul sebagaimana adanya tanpa melakukan analisis dan membuat kesimpulan yang umum. Secara lengkapnya, metode deskriptif analitis yaitu suatu metode penelitian dengan mengungkapkan masalah yang ada, mengolah data, menganalisis, meneliti dan menginterprestasikan serta membuat kesimpulan dan memberi saran yang kemudian disusun pembahasannya secara sistematis (Sugiyono, 2009). 
Dengan kata lain penelitian deskriptif analitis yaitu mengambil masalah atau memusatkan perhatian kepada masalah-masalah sebagaimana adanya saat penelitian dilaksanakan, hasil penelitian yang kemudian diolah dan dianalisis untuk diambil kesimpulannya untuk umum.

\section{HASIL PENELITIAN DAN PEMBAHASAN}

\section{Fenomena Perilaku Negatif Remaja}

Perkembangan zaman yang semakin modern sudah mulai mengikis karakter ke arah ketidakbaikan atau akblakul madzmumah, gejala ini juga terjadi pada peserta didik Sekolah Menengah Atas (SMA), yang merupakan produk global yang sangat rawan terhadap dekadensi moral sehingga mempunyai karakter yang lemah dan lebih mudah melakukan perbuatan yang tidak baik. Pada dasarnya jati diri atau karakter yang kuat hanya bisa dibentuk kalau kita memiliki dan membangun watak yang tanggung jawab di dalamnya terkandung konsistensi, integritas dan dedikasi, loyalitas dan komitmen secara vertikal (dengan sang Khalik, Allah Swt.) maupun secara horisontal (dengan sesama, masyarakat serta negara dan bangsa).

Dalam beberapa kasus, tidak sedikit perilaku remaja terjebak kepada perilaku negatif dan bahkan kriminal. Data dari tahun ke tahun menunjukkan peningkatan perilaku negatif remaja semakin nyata. Data Menkominfo tahun 2010 mengungkap 97\% remaja pernah menonton atau mengakses pornografi, $62,7 \%$ remaja pernah melakukan hubungan badan (making love), dan 21\% melakukan aborsi (www.kompas.com, 2010). Data terbaru menunjukkkan pengguna narkoba dari $\mathrm{BNN}$ justru meningkat signifikan dimana pada periode Juni 2015 angka pengguna sebesar 4.2 juta dan di bulan November 2015 sebesar 5,9 juta (www.indonesia.coconuts.co, 2016).

Beberapa kasus tersebut sebelumnya adalah contoh pada salah satu kabupaten yang ada di provinsi Jawa Barat. Pokok kuncinya adalah remaja merupakan salah satu usia yang terlibat di dalamnya. Usia remaja merupakan masa dengan labilitas emosi yang membutuhkan pendidikan karakter sehingga berperilaku yang baik sesuati dengan aturan dan norma yang berlaku.

\section{Urgensi Peran Sekolah dalam Mendidik Karakter Sisiwa}

\section{Dasar pemikiran peran sekolah dalam mendidik karakter siswa}

Fenomena yang menggambarkan buruknya akhlak remaja sebagaimana dikemukakan sebelumnya harus segera diatasi. Mencari alternatif solusi bukanlah perkara yang mudah. Mengoptimalkan fungsi lembaga pendidikan, baik informal, formal, dan nonformal perlu segera dilakukan.

Sekolah merupakan lembaga pendidikan formal yang dapat menjadi alternatif untuk mengatasi permasalahan buruknya akhlak remaja tersebut di atas. Hal tersebut sangat beralasan megingat dalam Peraturan Pemerintah Nomor 55 tahun 2007 tentang Pendidikan Agama dan Pendidikan Keagamaan, pasal 3 ditegaskan bahwa, "Setiap satuan pendidikan pada semua jalur, jenjang, dan 
jenis pendidikan wajib menyelenggarakan pendidikan agama."

Pembinaan karakter di sekolah merupakan bagian tak terpisahkan dari pembaruan dan pembangunan pendidikan nasional. Sebagimana dalam Penjelasan Umum Undang-Undang Nomor 20 Tahun 2003 tentang Sistem Pendidikan Nasional bahwa: "Pembaruan sistem pendidikan nasional memerlukan strategi tertentu. Salah satu strategi pembangunan pendidikan nasional itu adalah pendidikan agama serta akhlak mulia."

Pendidikan karakter di sekolah juga sangat terkait dengan manajemen sekolah. Manajemen yang dimaksud di sini adalah bagaiman pendidikan karakter direncanakan, dilaksanakan, dan dikendalikan dalam kegiatan-kegiatan pendidikan di sekolah secara memadai. Pengelolaan tersebut antara lain meliputi nilai-nilai yang perlu ditanamkan, muatan kurikulum, pembelajaran, penilaian, pendidik dan tenaga kependidikan, dan komponen terkait lainnya. Dengan demikian manajemen sekolah merupakan salah satu media yang efektif dalam pendidikan karakter di sekolah.

Upaya pembinaan karakter siswa yang baik di sekolah menjadi suatu keniscayaan (Firmansyah, 2017). Ditegaskan Maksudin bahwa karakter tidak terjadi secara tiba-tiba, akan tetapi membutuhkan proses. Proses yang dimaksud adalah upaya pembinaan melalui pendidikan karakter (Maksudin, 2013: 6). Pembinaan merupakan suatu usaha, tindakan, dan kegiatan yang dilakukan secara efisien dan efektif untuk memeroleh hasil yang lebih baik (Fathurrahman, 2013: 46).
Orang yang berkarakter menurut Lickona adalah sifat alami seseorang dalam merespon situasi secara bermoral yang dimanifestasikan dalam tindakan nyata melalui tingkah laku yang baik, jujur, bertanggung jawab, menghormati orang lain dan karakter mulia lainnya. Respon dari karakter tersebut menurut Aristoteles sangat erat kaitannya dengan "habit" atau kebiasaan yang terus menerus dilakukan. Sehingga menurut Lickona sangat penting mendidik karakter dengan menekankan pada tiga aspek yakni: knowing the good (mengetahui kebaikan), loving the good (mencintai kebaikan), dan acting the good (melakukan kebaikan). Oleh karena itu, Lickona menambahkan bahwa keberhasilan pendidikan karakter harus dimulai dengan pemahaman karakter yang baik, mencintainya, dan pelaksanaan atau peneladanan atas karakter yang baik itu (Lickona, 1992: 12\&22).

Agar karakter yang baik itu menjadi "habit", penting sekali mendapat bimbingan agama. Salah satu upaya tersebut adalah pembinaan yang nyata dari lingkungan. Sekolah merupakan lingkungan eksternal yang mempengaruhi kepribadian anak, karena sekolah adalah substitusi dari keluarga dan guru adalah substitusi dari orang tua. Tafsir mengemukakan bahwa strategi yang diunggulkan dalam belajar agama adalah knowing, doing, afekting, dan being. Pelaksanaannya dilakukan secara terpadu dengan peneladanan dan pembiasaan sebagai metode (Yusuf, 2008: 48-49).

\section{Pandangan tentang karakter siswa dapat dididik}

Kata karakter sesungguhnya berasal dari bahasa Latin: "kharakter", "kharassein", "kharax", dalam bahasa Inggris: character, 
dalam bahasa Indonesia: "karakter", dan dalam bahasa Yunani: character, dari charassein yang berarti membuat tajam, membuat dalam (Madjid \& Andayani, 2011: 11). Hendro Darmawan, et.al mengartikan karakter sebagai watak, tabiat, pembawaan, dan kebiasaan (Darmawan, et.al, 2010: 277).

Dalam bahasa Arab, karakter diartikan khuluq, sajiyyah, thabu'u (budi pekerti, tabiat atau watak), kadang juga diartikan syakhshiyyah yang artinya lebih kepada personality (kepribadian) (Supiana, 2011: 5). Istilah karakter secara harfiah berasal dari bahasa Latin "Charakter", yang antara lain berarti: watak, tabiat, sifat-sifat kejiwaan, budi pekerti, kepribadian atau akhlak. Sedangkan secara istilah, karakter diartikan sebagai sifat manusia pada umumnya dimana manusia mempunyai banyak sifat yang tergantung dari faktor kehidupannya sendiri (Buchari, 2018: 12).

Sedangkan menurut Ratna Megawati, karakter ini mirip dengan akhlak yang berasal dari kata kbuluk, yaitu tabiat atau kebiasaan melakukan hal-hal yang baik. Imam al-Ghazali menggambarkan bahwa karakter (akhlak) adalah tingkah laku seseorang yang berasal dari hati yang baik (Muslich, 2011: 71). Pengertian yang tidak berbeda juga dikemukakan Dharma Kesuma yang mengatakan bahwa arti kata karakter adalah budi pekerti, akhlak, moral, afeksi, susila, tabiat, dan watak memiliki arti yang sama (Kesuma, 2011: 24). Karakter dipengaruhi oleh faktor genetis dan faktor lingkungan seseorang. Pada sisi faktor lingkungan, maka karakter seseorang banyak dibentuk oleh orang lain yang sering berada di dekatnya atau yang sering mempengaruhinya, kemudian ia mulai meniru untuk melakukannya. Dengan demikian, dasar definisi tentang karakter ini memiliki asumsi bahwa dalam perkembangannya dapat dinina dan dididik melalui lingkungan dengan program di dalamnya, yang salah satunya adalah sekolah.

\section{Desain program pendidikan karakter di sekolah}

Keterpaduan beberapa bentuk kegiatan (intra kurikuler, ko-kurikuler, ekstra kurikuler, maupun pembiasaan) sudah saatnya secara optimal dilakukan di sekolah. Bentuk kegiatan itu harus sinergi satu sama lain dalam mewujudkan siswa yang memiliki karakter yang baik (Karin, N. \& Fakhruddin 2019).

Pendidikan karakter merupakan usaha kerjasama (antar individu) berhubungan dengan pelaksanaan yang dapat mencapai suatu tujuan yang telah ditetapkan berkaitan dengan pembentukkan perilaku yang baik. Oleh karena itu suatu upaya pendidikan karakter di sekolah harus mencakup program kegiatan, koordinasi pelaksanaan, pemantauan dan penilaian, dan indikator keberhasilan (Fathurrahman, 2013: 183\&192).

Dalam mempermudah suatu upaya pendidikan, diperlukan suatu model pembinaan karakter. Aan Hasanah mengenalkan model pendidikan karakter dengan nama basic model pendidikan karakter yang mencakup indikaktor tujuan, program, proses, dan evaluasi (Hasanah, 2013: 117).

Lalu, mengapa sekolah memiliki kedudukan sangat penting dalam pendidikan karakter siswa? Setidaknya terdapat dua dasar pemikiran yang 
melatarbelakanginya. Dasar pemikiran pertama berkaitan dengan optimalisasi peran sekolah dalam mendidik karakter yang baik bagi siswa yang tergolong masa remaja. Sekolah merupakan lembaga pendidikan formal yang harus ikut andil dalam mewujudkan tujuan pendidikan nasional sebagaimana ditegaskan dalam Undang-Undang Nomor 20 Tahun 2003 tentang Sistem Pendidikan Nasional yaitu menjadi manusia yang beriman dan bertakwa kepada Tuhan Yang Maha Esa, berakhlak mulia, sehat, berilmu, cakap, kreatif, mandiri dan menjadi warga negara yang demokratis serta bertanggung jawab. Pendidikan karakter siswa oleh sekolah baik program kegiatan, koordinasi pelaksanaan, pemantauan dan penilaian, dan indikator keberhasilan sangatlah penting sehingga siswa memiliki karakter yang baik dan mampu menjalani hidup dan bekerjasama baik dalam lingkup keluarga, masyarakat, bangsa, dan negara. Sedangkan dasar pemikiran kedua adalah kebermanfaatan program-program pendidikan karakter bagi siswa yang tergolong remaja. Masa remaja adalah masa yang penuh keguncangan jiwa, masa yang berada dalam peralihan atau di atas jembatan goyang, yang menghubungkan masa kanak-kanak yang penuh ketergantungan dengan masa dewasa yang matang dan berdiri sendiri. Bangsa ke depan tentu ada di pundak masa remaja sekarang.

Desain pendidikan karakter di sekolah cukup banyak dikemukakan para ahli. Misalnya Doni Koesoema memiliki konsep sebagai berikut. Pertama, desain berbasis karakter berbasis kelas. Desain ini berbasis pada hubungan guru sebagai pendidik dan siswa sebagai pembelajar di dalam kelas. Kedua, desain pendidikan karakter berbasis kultur sekolah. Desain ini membangun budaya sekolah yang mampu membentuk karakter anak didik dengan bantuan pranata sosial sekolah agar nilai tertentu terbentuk dan terbatinkan dalam diri siswa. Ketiga, desain pendidikan karakter berbasis komunitas dimana sekolah tidak secara sendirian, melainkan bekerjasama dengan lembaga-lembaga lain dalam membina karakter Islami siswa (Koesoema, 2011: 2).

Ketiga desain tersebut tentu harus diimplementasikan oleh sekolah secara terorganisir dan sistematis. Fathurrohman, et.al. (2013: 183-192) suatu upaya pembinaan mencakup; program kegiatan, koordinasi pelaksanaan, pemantauan dan penilaian, dan indikator keberhasilan. Berdasar kepada cakupan tersebut serta beberapa pengertian sebagaimana dipaparkan sebelumnya, pembinaan memiliki empat komponen inti yakni:

Kesatu, Program kegiatan pendidikan karakter. Program kegiatan adalah program yang digulirkan untuk pendidikan karakter. Program ini beragam tergantung kreativitas suatu SDM dalam suatu lembaga. Fathurrohman, et.al. menegaskan bahwa semua program kegiatan hendaknya peserta didik sebagai pusat dan pemeran utama. Kegiatan yang diselenggarakan agar diorganisir oleh peserta didik dengan bimbingan pendidik. Dengan demikian peserta didik memperoleh pengalaman langsung sehingga dapat melatih, menghayati, dan bertanggungjawab terhadapat tugas yang diamanahkan.

Kedua, Pelaksanaan program kegiatan. Pelaksanaan adalah menggerakkan seluruh sumber daya yang mencakup: manusia (man), bahan termasuk 
perlengkapan (material), metode (method), pembiayaan (money), dan waktu (time) untuk mencapai tujuan yang telah ditetapkan.

Ketiga, Pemantauan dan penilaian. Kegiatan pemantauan dan penilaian dilakukan untuk melihat kesesuaian program dengan pelaksannaannya sehingga diperoleh gambaran apakah seluruh sumber daya bekerja secara baik atau tidak.

Keempat, Indikator Keberhasilan. Indikator keberhasilan adalah pencapaian tujuan suatu program yang digulirkan. Untuk menentukan berhasil tidaknya suatu program, biasanya dilihat dari standar yang telah ditetapkan dari pencapaian suatu tujuan program.

\section{Model dan pendekatan dalam sistem pendidikan karakter di sekolah}

Model secara umum diartikan kerangka konseptual yang digunakan sebagai pedoman dalam melakukan suatu kegiatan (Majid\&Andayani, 2013: 115; Firmansyah et al. 2019). Dalam pendidikan karakter, model basic yang diadaptasi dari basic teaching model Robert Glaser sangat penting dipertimbangkan. Model basic ini diawali oleh tujuan yang mengarahkan seluruh program dan proses pada satu arah yang jelas. Program yang hendak dijalankan mesti mengarah pada tujuan yang hendak dicapai. Sementara proses akan mengimplementasi program yang dirumuskan dan dievaluasi akan mengukur berhasil atau tidaknya model yang dijalankan (Hasanah, 2013: 116).

Sebuat model yang diterapkan tentunya harus dipikirkan efektivitasnya dalam mencapai tujuan. Pemikiran efektivitas ini sangat penting oleh karena beberapa alasan sebagai berikut. Efektivitas berkaitan dengan perencanaan dengan pertimbangan aspek-aspek di dalamnya dan tujuan yang hendak dicapai dan pelaksanaan perencanaan yang telah disusun. Efektivitas suatu program juga memikirkan subjek sebagai pelaku pelaksana dan objek yang dilaksanakan yang di dalamnya terdapat sistem kerja, evaluasi efektivitas, dan hasil dari proses efektivitas memiliki feed back (umpan balik) bagi perbaikan ke depan.

Sumber daya manusia di sekolah, dan terutama kepala sekolah harus memahami konsep efektivitas sebuah program, tak terkecuali pendekatan-pendekatan di dalamnya yakni sumber daya, proses, dan pencapaian tujuan. Martani dan Lubis (1987: 55) menjelaskan pendekatan dalam mengukur efektivitas organisasi, yakni pendekatan sumber (resource approach) yang menekankan pada input yang terlibat dalam suatu program. Pendekatan proses (process approach) yang menekankan pada pelaksanaan program dimana di dalamnya seluruh komponen berperan dan suatu sistem. Pendekatan sasaran (goals approach) yang menekankan pada pencapaian tujuan sebagai hasil akhir dari target yang direncanakan.

Dalam memberlakukan suatu program pendidikan karakter di sekolah, setidaknya prosedur di bawah ini harus menjadi pertimbangan. Kelima prosedur ini ditawarkan Sudjana (2004: 236-237) dengan penjelasan sebagai berikut. Pertama, Mengumpulkan informasi; Informasi yang dihimpun melalui kenyataan atau peristiwa yang benarbenar terjadi dalam kegiatan berdasarkan rencana yang telah ditetapkan. Pengumpulan informasi yang dianggap efektif adalah yang dialkukan secara 
berkala dan berkelanjutan dengan menggunakan pemantauan dan penelaahan laporan kegiatan.

Kedua, Mengidentifikasi masalah; Masalah ini diangkat berdasarkan informasi langkah pertama. Masalah akan terjadi apabila terjadi ketidaksesuaian dengan atau penyimpangan dari kegiatan yang telah direncanakan.

Ketiga, Menganalisis masalah. Kegiatan analisis adalah untuk mengetahui jenis-jenis masalah dan faktor penyebab timbulnya masalah tersebut.faktor itu mungkin datang dari para pelaksana kegiatan, sasaran kegiatan, fasilitas, biaya, proses, waktu, kondisi lingkungan dan lain sebagainya.

Keempat, Mencari dan menetapkan alternatif pemecahan masalah; Kegiatan pertama yang perlu dilakukan adalah mencari alternatif pemecahan masalah. Alternatif ini disusun setelah memperhatikan sumber-sumber pendukung dan hambatan yang mungkin akan ditemui dalam memecahkan masalah. Kegiatan selanjutnya adalah menetapkan prioritas upaya pemecahan masalah yang dipilih dari alternatif yang ada.

Kelima, Melaksanakan upaya pemecahan masalah; Upaya ini dapat dilakukan oleh pembina baik secara langsung mapun secara tidak langsung. Secara langsung apabila upaya pembinaan dilakukan oleh pembina kepada pihak yang dibina dalam pada kegiatan itu berlangsung. Secara tidak langsung apabila upaya pemecahan masalah dilakukan oleh pembina dengan melalui pihak lain.

Pembinaan terhadap siswa mempunyai arti khusus, yaitu usaha atau kegiatan memberikan bimbingan, arahan, pemantapan, peningkatan arahan terhadap pola pikir, sikap mental, serta perilaku, minat dan bakat dalam mendukung program ekstra-kurikuler untuk keberhasilan program kurikuler, memantapkan kegiatan ekstrakurikuler dalam menunjang pencapaian kurikulum, meningkatkan apresiasi dan penghayatan diri. menumbuhkan sikap berbangsa dan bernegara, meneruskan dan mengembangkan jiwa semangat serta nialai-nilai 1945, dan meningkatkan kesegaran jasmani dan rohani.

Secara yuridis, pengembangan kegiatan ekstrakurikuler mempunyai landasan hukum yang kuat, karena sudah diatur dalam surat Keputusan Menteri (Kepmen) yang harus dilaksanakan oleh sekolah mapun madrasah. Salah satu Kepmen yang mengatur kegiatan ekstrakurikuler adalah Keputusan Menteri Pendidikan Nasional RI No. 125/U/2002 tentang kalender pendidikan dan jumlah belajar efektif di sekolah. Pada bagian keputusan itu dijelaskan halhal sebagai berikut :

Bab V pasal 9 ayat 2; Pada tengah semester 1 dan 2 sekolah melakukan kegiatan olah raga dan seni (Porseni), karyawisata, lomba kreatifitas atau praktik pembelajran yang bertujuan untuk mengembangkan bakat, kepribadian dan prestasi dan kreativitas siswa dalam rangka mengembangkan pendidikan anak seutuhnya.

Bagian Lampiran Keputusan Mendiknas Nomor 125/U/2002 Tanggal 31 Juli 2002; Liburan sekolah atau madrasah selama bulan Ramadhan diisi dan dimanfaatkan untuk melaksanakan berbagai kegiatan yang diarahkan pada peningkatan akhlak mulia, pemahaman, pendalaman dan amaliyah agama 
termasuk kegiatan ekstrakurikuler lainnya yang bermuatan moral (Mulyana, 2004: 211).

Berdasarkan penjelasan di atas, dapat diambil pengertian tentang pembinaan yakni "usaha yang dilakukan untuk mengubah sebuah pola dengan melalui berbagai tahapan-tahapan yang terstruktur untuk mencapai sesuatu yang diinginkan."

Ajaran Islam memiliki tiga fondasi pokok yaitu; akidah, syari'ah dan akhlak. Akidah berkenaan dengan keimanan. Syari'ah berkenaan dengan aturan-aturan yang harus dilaksanakan manusia dalam rangka mengabdikan diri pada Allah. Sedangkan akhlak adalah perilaku yang ditampilkan seseorang dalam kesehariannya berkaitan dengan hubungan dengan Allah, manusia atau makhluk lainnya (Daulay \& Pasa, 2016: 53). Dengan demikian, pembinaan akhlak siswa melalui suatu program pendidikan karakter siswa di sekolah harus terprogram dan sistimatis.

Menurut Fathurrohman, et.al. (2013: 183-192) suatu upaya pembinaan harus mencakup; program kegiatan, koordinasi pelaksanaan, pemantauan dan penilaian, dan indikator keberhasilan. Berdasar kepada cakupan tersebut serta beberapa pengertian sebagaimana dipaparkan sebelumnya, pembinaan memiliki empat komponen inti yakni: Pertama, Program kegiatan pembinaan. Program kegiatan adalah program yang digulirkan untuk pembinaan. Program pembinaan ini beragam tergantung kreativitas suatu SDM dalam suatu lembaga. Fathurrohman, et.al. menegaskan bahwa semua program kegiatan pembinaan hendaknya peserta didik sebagai pusat dan pemeran utama. Kegiatan yang diselenggarakan agar diorganisir oleh peserta didik dengan bimbingan pendidik. Dengan demikian peserta didik memeroleh pengalaman langsung sehingga dapat melatih, menghayati, dan bertanggungjawab terhadapat tugas yang diamanahkan.

$\begin{array}{crr}\text { Kedua, } & \text { Pelaksanaan } & \text { program } \\ \text { kegiatan. } & \text { Pelaksanaan } & \text { adalah }\end{array}$
menggerakkan seluruh sumber daya yang mencakup: manusia (man), bahan termasuk perlengkapan (materia), metode (method), pembiayaan (money), dan waktu (time) untuk mencapai tujuan yang telah ditetapkan.

Ketiga, Pemantauan dan penilaian. Kegiatan pemantauan dan penilaian dilakukan untuk melihat kesesuaian program dengan pelaksanaannya sehingga diperoleh gambaran apakah seluruh sumber daya bekerja secara baik atau tidak.

Keempat, Indikator Keberhasilan. Indikator keberhasilan adalah pencapaian tujuan suatu program yang direncanakan dan dilaksanakan. Untuk menentukan berhasil tidaknya suatu program, biasanya dilihat dari standar yang telah ditetapkan dari pencapaian suatu tujuan program.

Dalam ranah kajian perilaku organisasi, Steers (1985: 209-212) mengemukakan tiga pendekatan dalam memahami efektivitas. Pendekatanpendekatan tersebut antara lain pendekatan tujuan (the goal optimization approach), pendekatan sistem (sistem theory approach), dan pendekatan kepuasan partisipasi (participant satisfaction model).

Pertama, Pendekatan tujuan merupakan suatu pendekatan dimana organisasi berlangsung dalam upaya mencapai suatu tujuan. Oleh karena itu, dalam pendekatan efektivitas ini 
dipandang sebagai goal attainment/goal optimization atau pencapaian sasaran dari upaya bersama. Derajat pencapaian sasaran menunjukkan derajat efektivitas. Suatu program dikatakan efektif jika tujuan akhir program tercapai. Dengan perkataan lain, pencapaian tujuan merupakan indikator utama dalam menilai efektivitas.

Kedua, Pendekatan sistem yang memandang efektivitas sebagai kemampuan organisasi dalam mendayagunakan segenap potensi lingkungan serta memfungsikan semua unsur yang terlibat. Efektivitas diukur dengan meninjau sejauh mana berfungsinya unsur-unsur dalam sistem untuk mencapai tujuan.

Ketiga, Pendekatan kepuasan partisipasi yakni dimana individu partisipan ditempatkan sebagai acuan utama dalam menilai efektivitas. Hal ini didasarkan pada asumsi bahwa keberadaan organisasi ditentukan oleh kualitas partisipasi kerja individu. Selain itu, motif individu dalam suatu organisasi merupakan faktor yang sangat menentukan kualitas partisipasi. Sehingga, kepuasan individu menjadi hal yang penting dalam mengukur efektivitas organisasi.

Steers melanjutkan bahwa dalam menjalankan pendekatan efektivitas, terdapat empat faktor yang mempengaruhi yakni karakteristik organisasi, karakteristik lingkungan, karakteristik SDM, dan karakteristik manajemen.

Berbeda dengan Mangunhardjana yang menawarkan beberapa pendekatan yang harus diperhatikan dalam pendidikan karakter siswa. Pertama ada pendekatan informatif (informative approach). Menurutnya pendekatan ini adalah cara menjalankan program dengan menyampaikan informasi kepada peserta didik. Peserta didik dalam pendekatan ini dianggap belum tahu dan tidak punya pengalaman. Selanjutnya pendekatan partisipatif (participative approach), dimana dalam pendekatan ini peserta didik dimanfaatkan sehingga lebih ke situasi belajar bersama. Kemudian pendekatan eksperiansial (experienciel approach), dalam pendekatan ini menempatkan bahwa peserta didik langsung terlibat di dalam pembinaan, ini disebut sebagai belajar yang sejati, karena pengalaman pribadi dan langsung terlibat dalam situasi tersebut.

Menurut Sudjana (2004: 229), terdapat dua pendekatan yang dapat digunakan dalam pembinaan, yaitu dengan menggunakan pendekatan langsung (direct contact) dan atau pendekatan tidak langsung (indirect contact). Pendekatan pertama terjadi apabila pihak pembina (pimpinan, pengelola, pengawas, supervisor, dan lainnya) melakukan pembinaan melalui tatap muka dengan yang dibina atau dengan pelaksana program. Pendekatan langsung dapat dilakukan dengan kegiatan diskusi, rapatrapat, tanya jawab, kunjungan lapangan, kunjungan rumah, dan lain sebagainya. Sementara pendekatan tidak langsung terjadi apabila pihak yang membina melakukan upaya pembinaan kapada pihak yang dibina melalui media masa seperti melalui petunjuk tertulis, korespondensi, penyebaran buletin dan media elektronik.

Tak selamanya seorang siswa berada di sekolah. Sekali-sekali para siswa berada di luar lingkungan sekolah. Kondisi tersebutlah yang merupakan tantangan 
tersendiri bagi SDM di sekolah untuk melakukan inovasi dalam pendidikan karakter siswa. Berkaitan dengan hal itu, diperlukan tahap-tahap dalam pendidikan karakter yakni tahap penyadaran, kemudian tahap pemberian wawasan, dan tahap pembentukkan inisiatif.

Dalam mengevaluasi suatu program pembinaan, Tayibnafis (2000: 23-36) menjelaskan pendekatan sebagai berikut :

Pendekatan pertama dalah eksperimental (experimental approach). Pendekatan ini berasal dari kontrol eksperimen yang biasanya dilakukan dalam penelitian akademik. Tujuannya untuk memperoleh kesimpulan yang bersifat umum tentang dampak suatu program tertentu dengan mengontrol sabanyak-banyaknya faktor dan mengisolasi pengaruh program.

Pendekatan kedua adalah yang berorientasi pada tujuan (goal oriented approach). Pendekatan ini memakai tujuan program sebagai kriteria untuk menentukan keberhasilan. Pendekatan ini amat wajar dan praktis untuk desain pengembangan program. Pendekatan ini memberi petunjuk kepada pengembang program, menjelaskan hubungan antara kegiatan khusus yang ditawarkan dengan hasil yang akan dicapai.

Pendekatan ketiga adalah yang berfokus pada keputusan (the decision focused approach). Pendekatan ini menekankan pada peranan informasi yang sistematik untuk pengelola program dalam menjalankan tugasnya. Sesuai dengan pandangan ini, informasi akan amat berguna apabila dapat membantu para pengelola program membuat keputusan. Oleh sebab itu, evaluasi harus direncanakan sesuai dengan kebutuhan untuk keputusan program.
Pendekatan keempat adalah yang berorientasi pada pemakai (the user oriented approach). Pendekatan ini memfokuskan pada masalah utilisasi evaluasi dengan penekanan pada perluasan pemakaian informasi. Tujuan utamanya adalah pemakaian informasi yang potensial. Evaluator dalam hal ini menyadari sejumlah elemen yang cenderung akan mempengaruhi kegunaan evaluasi, seperti cara-cara pendekatan dengan klien, kepekaan, faktor kondisi, situasi seperti kondisi yang telah ada (pre-existing condition), keadaan organisasi dengan pengaruh masyarakat, serta situasi dimana evaluasi dilakukan dan dilaporkan. Dalam pendekatan ini, teknik analisis data, atau penjelasan tentang tujuan evaluasi memang penting, tetapi tidak sepenting usaha pemakai dan cara pemakaian informasi.

Pendekatan kelima adalah yang responsif (the responsive approach). Pendekatan responsif menekankan bahwa evaluasi yang berarti adalah evaluasi yang mencari pengertian suatu isu dari berbagai sudut pandang semua orang yang terlibat, berminat, dan berkepentingan dengan program (stakeholder program). Evaluator menghindari satu jawaban untuk suatu evaluasi program yang diperoleh dengan memakai tes, kuesioner, atau analisis statistik, sebab setiap orang yang dipengaruhi oleh program merasakannya secara unik. Evaluator mencoba menjembatani pertanyaan yang berhubungan dengan melukiskan atau menguraikan kenyataan melalui pandangan orang-orang tersebut. Tujuan evaluasi adalah untuk memahami ihwal program melalui berbagai sudut pandang yang berbeda. 


\section{KESIMPULAN}

Tinjauan dalam berbagai aspek, sekolah memiliki kedudukan sangat penting setelah keluarga dalam mendidik karakter anak. Setidaknya ada empat kegiatan sekolah yang dapat dijadikan fasilitas untuk mendidik karakter, yakni intrakurikuler,

ko-kurikuler, esktrakurikuler, dan pembiasaan. Secara konseptual, sekolah dapat mengadopsi teori-teori model, desain, dan pendekatan pendidikan karakter siswa sehingga pelaksanaan program tersebut berjalan secara sistematis dan sistemik.

Di sisi lain remaja sebagai subjek belajar di sekolah dalam sisi perilakunuya sedang berada pada fase transisi yang cukup rentang terbawa arus negatif. Memikirkan formula yang tepat untuk mendidik karakter generasi muda sebagai penerus bangsa adalah fokus yang lebih mengemuka di tanah air ini. Kesibukan orang tua, lingkungan sosial, komunitas, dan termasuk media sosial memiliki andil dalam membentuk perilaku remaja. Tak jarang para remaja terpengaruh, hingga melakukan tindakan-tindakan yang mencerminkan karakter yang buruk.

Artikel ini merupakan hasil pemikiran mendalam mengenai pentingnya sekolah mengambil peran dalam mendidik karakter remaja. Artikel ini merekomendasikan bahwa stakehorders harus matang secara konseptual mengenai desain, model, dan pendekatan pendidikan karakter yang akan digulirkan sehingga berjalan secara efektif.

\section{REFERENSI}

Badan Narkotika Kabupaten Bandung Barat, Juni 2016.
Buchari, M., 2018, Character Building dan Pendidikan Kita, Kompas, dikutip 12 Desember.

Darajat, Z., (1989), Kesehatan Mental, Jakarta: Gunung Agung.

Darmawan, H., et.al, 2010, Kamus Ilmiah Populer Lengkap. Yogyakarta: Bintang Cemerlang.

Departemen Pendidikan Nasional, 2003. Undang-Undang Republik Indonesia Nomor 20 Tahun 2003 tentang Sistem Pendidikan Nasional. Jakarta: Pusat Data dan Informasi Pendidikan, Balitbang-Depdiknas.

Dokumen Reskrim Polres Cimahi, Juni 2016.

Fathurrohman, P. et.al., (2013), Pengembangan Pendidikan Karakter, Bandung: Refika Aditama.

Farida Yusuf Tayibnafis, Evaluasi Program, (Jakarta: Rineka Cipta, 2000), 23-36.

Firmansyah, M. I., 2017, Program Pembudayaan Terpadu dalam Membina Karakter Islami pada Siswa Sekolah Dasar Sebagai Implementasi Kurikulum "Bandung Masagi". Jurnal Pendidikan Agama Islam -Ta'lim Vol. 15 No. 2 2017.

Firmansyah, M.I., Tantowi, Y.A. \& Fawziah, G.R., 2019. MODEL TEAMS GAMES TOURNAMENT: Suatu Analisis Hasil Implementasi dalam Pembelajaran Pendidikan Agama Islam. TARBAWY: Indonesian Journal of Islamic Education, 6(2), pp.104-113. https://doi.org/10.17509/t.v6i2.205 83

Hasanah, A., (2013), Pendidikan Karakter Berperspektif Islam, Bandung: Insan Komunika.

Karin, Nurul \& Fakhruddin, A., 2019. Pengembangan Kurikulum PAI di SMP Darul Hikam Internasional School dalam Rangka Penguatan Pendidikan Katakter. TARBAWY: Indonesian Journal of Islamic Education, $4(2)$,

pp.251-274. 
https://doi.org/10.17509/t.v6i1.194 65

Kesuma, D., et.al., 2011, Pendidikan Karakter: Kajian Teori dan Praktik di Sekolah. Bandung: PT. Remaja Rosdakarya.

Koesoema, D., (2011), Pendidikan Karakter Strategi Mendidik Anak di Zaman Global, Jakarta: Gramedia.

Lickona, T., (1992), Educating for Character, How Our School Can Teach Respect and Responsibility, New York: Bantam Books.

Maesaroh, S., Abdussalam, A. \& Surahman, C., 2018. EFEKTIVITAS METODE USWAH HASANAH DALAM PROSES PEMBELAJARAN PAI (Studi Eksperimen di SMPN 29 Bandung). TARBAWY: Indonesian Journal of Islamic Education, 5(2), pp.123-136. https://doi.org/10.17509/t.v5i2.167 37

Majid, A. dan Handayani, D., (2013), Pendidikan Karakter Perspektif Islam, Bandung: Remaja Rosdakarya.

Maksudin, (2013), Pendidikan Karakter Non-Dikotomik, Yogyakarta: Pustaka Pelajar.

Mangunhardjana, Pembinaan, Arti dan Metodenya, (Yogyakarta:Kanimus, 2006

Martani, H. dan Hari L., (1987), Teori Organisasi, Bandung: Ghalia Indonesia.

Muslich, M. 2011, Pendidikan Karakter Menjawab Tantangan Krisis Multidimensional. Jakarta: Bumi Aksara.

Musthofa, A., (1997), Akblak Tasawnf, Bandung: Pustaka Setia.

Nata, A., (1996), Akblak tasawnf, Jakarta: Raja Grafindo Persada.

Peraturan Pemerintah Nomor 55 Tahun 2007, Pendidikan Agama dan Pendidikan Keagamaan. Jakarta.

Pusat Pelayanan Terpadu Pemberdayaan Perempuan dan Anak (P2TP2A)
Kabupaten Bandung Barat tahun 2016.

PLP2 Dinas Kesehatan Kabupaten Bandung Barat, Juni 2016.

Richard M. Steers, et al. (1985), Efektivitas Organisasi. Jakarta: Erlangga.

Sudjana, H.D, 2004, Manajemen Program Pendidikan untuk Pendidikan Nonformal dan Pengembangan Sumber Daya Manusia, Bandung: Falah Production.

Supiana, 2011, Mozaik Pemikiran Islam: Bunga Serampai Pemikiran Pendidikan Indonesia. Jakarta: Dirjen Dikti

Tafsir, A., 2010, Pendidikan Karakter Berbasis Pendidikan Agama, Makalah, Yogjakarta, 08-10 April 2010.

Undang-undang Nomor 20 Tahun 2003 tentang Sistem Pendidikan Nasional, Jakarta.

www.kompas.com, 210 Mei 010

www.indonesia.coconuts.co, 2016

Zainuddin, (1991), Seluk-Beluk Pendidikan Al-Ghozali, Jakarta: Bina Aksara. 